\title{
Seasonal succession of cyanoprokaryotes in a hypereutrophic oligo- mesohaline lagoon from the South of France
}

\author{
Nicolas Chomérat ${ }^{\mathrm{a},{ }^{*}}$, Robert Garnier $^{\mathrm{b}}$, Céline Bertrand ${ }^{\mathrm{b}}$ and Arlette Cazaubon ${ }^{\mathrm{b}}$ \\ a IFREMER, Station de Concarneau, Laboratoire Environnement et Ressources, 13, rue de Kérose, 29187 \\ Concarneau Cedex, France \\ b Institut Méditerranéen d'Écologie et de Paléoécologie, UMR-CNRS 6116, Écologie des Eaux Continentales \\ Méditerranéennes, C31, Université Paul Cézanne, Faculté de St-Jérôme, 13397 Marseille Cedex 20, France \\ *: Corresponding author : nicolas.chomerat@ifremer.fr
}

\begin{abstract}
:
The Bolmon lagoon (South of France) is an oligo-mesohaline coastal lagoon that has undergone intense eutrophication in the past decades, resulting from a strong concentration of human activities in its drainage basin. Consequently, it exhibits some characteristics typical of an advanced trophic state; namely, the disappearance of submerged vegetation, the permanently intense phytoplankton growth and the recurrence of cyanoprokaryote blooms. As cyanoprokaryote dominance in south-temperate saline lagoons is little reported, we carried out this study in order to understand the seasonal variations in the phytoplankton composition and biomass, and to analyse the influence of environmental parameters such as salinity, nutrients and climate on the seasonal succession of species. In this lagoon, the phytoplankton was permanently dominated by cyanoprokaryotes, probably because of high availability of nutrients, low light penetration in the water column and frequent turbulent mixing induced by wind. The two most abundant species Planktothrix agardhii (in winter-spring) and Pseudanabaena limnetica (in summer) have low light requirements and are well adapted to a high mixing frequency, which defines the S1 functional group in Reynolds' typology for phytoplankton. Although widely studied in north-temperate lakes, blooms of these typically freshwater species are almost unreported in the Mediterranean area, especially in brackish ecosystems that are not their normal habitat. In the Bolmon lagoon, all their requirements for nutrients, light and mixing are satisfied and they seem to cope with a moderate presence of salt but P. agardhii was less competitive than P. limnetica at highest salinities, the latter being probably more halophytic. Contrary to the observations in lakes located at higher latitudes, the Mediterranean climate seems to induce a typical seasonal pattern of succession characterised by the dominance of $P$. agardhii (winter) - Chroococcales (spring) - Pseudanabaenaceae (summer) - P. agardhii (autumn, winter). The warm temperatures seemed to have a major influence on the phytoplankton succession, being responsible for the survival of Planktothrix during winter and its rapid and intense development in early spring. Intense mixing and high irradiance in summer promoted the development of Pseudanabaenaceae, as reported in another south-temperate lagoon, the Albufera of Valencia (Spain). The ecological success of Oscillatoriales observed in the Bolmon lagoon is a perfect example of a shift to the "turbid stable state" as proposed for freshwater shallow lakes only. Our work demonstrated that hypereutrophic Mediterranean lagoons can function very similarly to shallow lakes at higher latitudes; but the warmer climate and higher irradiances are probably responsible for differences in the seasonal pattern of species dominance.
\end{abstract}

Keywords: brackish water; lagoon; ecology; cyanoprokaryotes; Mediterranean area; phytoplankton; Planktothrix agardhii; Pseudanabaena limnetica; turbid state 


\section{Introduction}

Lagoons, in their narrowest sense, are natural physiographic features consisting of shallow, open masses of saline or brackish water which are either isolated or semi-isolated from the adjacent sea by a barrier of sand or shingle, but which receive salt from the sea as the result of natural causes (Healy, 1997). These aquatic environments, characterised by seasonal variations in water volume and salinity level, harbour species-poor communities of brackish plants and animals showing high rates of productivity (Barnes, 1980). Lagoons can function very differently, depending on the amount and frequency of water exchange with the sea. Their status mid-way between continental and marine conditions (Boutière, 1974) makes them of major ecological interest. Since the life expectancy of these ecosystems is very short in terms of geological time, they are particularly fragile and have therefore become one of the priority targets for conservation efforts (Healy, 1997; Bazaïri et al., 2003). Because of their position at the end of drainage basins, which are often enriched in nitrogen and phosphorous by human activities (Cloern, 2001), lagoons have undergone natural processes of eutrophication. As a biological consequence, primary producers often proliferate (Menéndez and Comin, 2000), increasing the demand for oxygen needed for biological degradation processes. This may, under certain climatic conditions, lead to dystrophic crises detrimental to the entire ecosystem (Harzallah and Chapelle, 2002). As in shallow lakes, extreme eutrophication and resulting increased phytoplankton growth may drastically reduce light availability in the water column, and benthic vegetation is likely to disappear (Scheffer, 2001; Abrantes et al., 2006). Reduced light can also be detrimental to less tolerant phytoplankton species and induce dramatic alterations in their composition. In the most degraded ecosystems, populations become dominated by autotrophic cyanoprokaryote (cyanobacteria) species (Barica and Mur, 1980; Paerl, 1996; Scheffer et al., 1997), leading to a subsequent reduction in biodiversity (Abrantes et al., 2006). The potential toxinogenicity of several species and the formation of blooms also constitute nuisances which disturb the lakeside human populations and limit the recreational use of the waters (Reynolds, 1987; Paerl, 1988a; Codd, 2000).

On the Mediterranean coast, almost all of the lagoons were intensively used for centuries as fishery grounds and their subsequent use as outlets for domestic and industrial wastewater, led to their eutrophication (Vicente and Miracle, 1992; Pastres et al., 2004). However, hypereutrophic conditions and occurrence of cyanoprokaryotes blooms have been studied in only a few lagoons from this area (Romo and Miracle, 1993; Sorokin et al., 2004) and the seasonal succession of phytoplankton in other similar systems is poorly understood. In European countries, ecological data are required to support the implementation of the Water Framework Directive (European Union, 2000) which is the legal mechanism for maintaining and improving the ecological quality of fresh 
and coastal waters (Loureiro et al., 2006). But more generally, since the Mediterranean climate is not only present in Europe, but also in various locations around the world, it is very important to collect data from such ecosystems in order to develop general ecological models, which incorporate a climatic gradient, for shallow lakes and lagoons (e.g. van de Bund et al., 2004).

In that context, we aim to study the phytoplankton composition and seasonal dynamics in the Bolmon lagoon, located in southern France, where important changes have occurred during the past decades. Almost all the covering by submerged macrophytes has disappeared from this oligo- to mesohaline lagoon because of the intense proliferations of phytoplankton. In the recent past years, the lagoon has shifted to a hypereutrophic state associated with frequent cyanoprokaryote blooms and, consequently, fishing and all water sports activities have been forbidden since the late 1990s. In spite of its severely degraded water quality, the lagoon and its vicinity remain of a considerable importance for biodiversity. Actually, it is a priority for conservation since the surrounding marshes and sandhills promote a high floristic diversity and constitute a sanctuary for many bird species. To evaluate the influence of climate and other abiotic environmental factors on the phytoplankton succession, and for comparison with eutrophic ecosystems from higher latitudes, we analyse the variations in the composition of the cyanoprokaryote community during an annual cycle. In particular, we focus on environmental parameters such as the salinity, nutrient concentrations and weather conditions, since these are major factors expected to influence phytoplankton succession and cyanoprokaryotes dominance.

\section{Material and methods}

\subsection{Study area}

The Bolmon lagoon (Étang de Bolmon) is located in South-East France (432 $\left.25^{\prime} \mathrm{N} ; 5^{\circ} 10^{\prime} \mathrm{E}\right)$, near Marseilles (Fig. 1). It measures about $5 \mathrm{~km}$ long, up to $1.5 \mathrm{~km}$ wide, and is $0.58 \mathrm{~km}^{2}$ in area. The maximum depth is $2.2 \mathrm{~m}$, but the average value is only about $1 \mathrm{~m}$ owing to the large amount of accumulated organic sediment. Because of its shallowness and its exposure to strong winds, this lagoon has a high water turnover and never stratifies for periods longer than a few days in early summer, under high irradiance and calm conditions. The annual hydrological data show the mean residence time of the water to be about 2 months with, however, a gradual increase to 3.5 months during the spring and summer caused by the Mediterranean drought.

The Bolmon lagoon can be classified as a secondary lagoon, since it does not communicate directly with the Mediterranean Sea. Brackish water is exchanged only with the Berre lagoon, which is a large brackish area of $155 \mathrm{~km}^{2}$, mostly polyhaline, that opens onto Mediterranean Sea via the 
Caronte canal (Fig. 1). Exchanges occur with the Bolmon lagoon via three canals dug through the sand bar. During windy conditions, salty water can also enter the Bolmon lagoon via the Rove canal that runs alongside the south shore of the lagoon (Fig. 1). This canal was constructed early in the $20^{\text {th }}$ century to connect the Berre lagoon with Marseilles harbour, but it was not used for long because of tunnel cave-ins. Though still open to the Berre lagoon, the other end is now closed; and so most of the time the canal water is brackish, and similar to that of the Bolmon lagoon. A single tributary, the $12 \mathrm{~km}$ long Cadière River, provides the main freshwater input.

\subsection{Sampling}

Ten sampling stations were chosen across this lagoon because of the differing conditions and water inputs, and one station (numbered 11) was also located on the Rove Canal (Fig. 1). Stations 1, 2 and 3 were located on the canals communicating with the Berre lagoon. On the southern shore, stations 4 and 6 were located near the channels communicating with the Rove canal. Temperature and conductivity profiles were recorded at station 5, which was located in the region of maximum depth (mean depth $1.90 \mathrm{~m}$ ) and surface measurements were made in all other stations. Station 7 was located in the mouth of the Cadière River, where fresh water enters the lagoon. This is the only tributary reaching the lagoon; its drainage basin is heavily urbanised and it receives a large amount of untreated domestic sewage, accounting for the lagoon's high phosphate and nitrate concentrations. In the river, annual average concentrations $(n=12)$ of dissolved inorganic nitrogen (DIN) and soluble reactive phosphorus (SRP) were $470 \pm 166 \mu \mathrm{M}$ and $18 \pm 7 \mu \mathrm{M}$, respectively (unpublished data). Station 8 was located in the northern part of the lagoon, while stations 9 and 10 were chosen in its middle, in order to draw transects across the lagoon (Fig. 1).

Material was collected for this study just below the surface with a sampling bottle, twice a month during January, February and March 2002 because of green-waters caused by cyanoprokaryote peak previously observed at this season, and then once a month up to December 2002. In total, 165 samples were collected and analysed. One-litre subsamples were used for physical and chemical analyses and $500 \mathrm{ml}$ subsamples were preserved in 5\% buffered formaldehyde and subsequently used for phytoplankton counts. About $200 \mathrm{ml}$ subsamples were kept fresh to ensure correct identification of fragile species and avoid deformations subsequent to the fixation. 


\subsection{Environmental parameters}

The mean irradiance and rainfall for ten-day periods were provided by the Meteorological station at Marseilles-Provence Airport, less than $1 \mathrm{~km}$ from the northern shore of the lagoon. In the multivariate analysis, we took the mean irradiance during the four days prior to the sampling day and the sampling day itself ( $n=5$ days), in order to take into account the conditions previously encountered by the organisms during their growth.

At each of the stations, field measurements were made of temperature and salinity using a WTW Oxi 197 oxythermometer and a WTW LF330 conductimeter respectively. Transparency depth $\left(Z_{s}\right)$ was measured with a $25 \mathrm{~cm}$ diameter Secchi disk in stations where light did not reach the bottom of the lagoon. Underwater photosynthetically active radiation (PAR) was measured each $0.5 \mathrm{~m}$ from just below the surface down to the bottom using a 2 pi underwater quantum sensor (Li-Cor LI192SA). At each station, the vertical attenuation $(E)$ was calculated from the profile values as described by Scheffer (2001) and the product $E D$ (where $D$ is the average depth of the lagoon) was taken as an index to the "underwater shade" climate (Scheffer et al., 1997). pH was measured in the laboratory (Metrohm-Herisau Titriskop E516), and alkalinity and nutrient analyses were carried out in line with the AFNOR recommendations (AFNOR, 1979) and Mackereth et al. (1978). DIN (dissolved inorganic nitrogen) was assessed by calculating the sum of $\mathrm{N}-\mathrm{NO}_{3}, \mathrm{~N}-\mathrm{NO}_{2}$ and $\mathrm{N}-\mathrm{NH}_{4}$. At the deepest station S5, temperature and salinity profiles were measured. The stability of the water column was estimated in terms of the square of the Brunt Väisälä, or buoyancy, frequency, $N^{2}$ (Nixdorf, 1994):

$$
N^{2}=\left(g / \rho^{\prime}\right) \frac{\mathrm{d} \rho}{\mathrm{d} z}
$$

where $\frac{\mathrm{d} \rho}{\mathrm{d} z}$ is the mean density gradient between the surface and bottom; $\rho$ ' the mean density given by $\left(\rho_{0}+\rho_{\text {bottom }}\right) / 2$ and $g$ the gravitational acceleration $\left(9.81 \mathrm{~ms}^{-2}\right)$. In order to calculate the water density, we used the values recorded in the temperature and salinity profiles in the equations corrected for salinity (McCutcheon et al., 1993).

\subsection{Phytoplankton analysis}

For quantitative phytoplankton analysis, subsamples (from $200 \mu \mathrm{l}$ to $2.5 \mathrm{ml}$ ) of preserved material were put in $10 \mathrm{ml}$ Utermöhl counting chambers, then filled with filtered water (1.2 $\mu \mathrm{m}$ pores $)$. After settling (Utermöhl, 1958), at least 400 cells of the most abundant species were counted in one or more diametrical bands at x 400 magnification using an Olympus IX70 inverted microscope equipped with phase contrast and a calibrated micrometer. The cells in each colony were counted (or estimated in the case of species forming smaller colonies), and each trichome was measured to 
estimate the number of cells, based on a calibration step drawn up with 10 trichomes from each sample. Biovolume of cyanoprokaryotes was calculated multiplying trichome length or cell number by the volume estimated by simple geometric models (Sun and Liu, 2003).

Taxa were identified as described by Anagnostidis and Komárek (1985; 1988); Komárek and Anagnostidis (1999; 2005).

\subsection{Statistical analyses}

Statistical analyses and tests were performed as described by Sokal and Rholf (2000) using R software (R Development Core Team, 2004) completed with the ade4 package (Thioulouse et al., 2004) and the vegan library (Oksanen, 2005). These software programs were used in making a canonical correspondence analysis (CCA) to analyse the relationships between the species and environmental variables (Ter Braak, 1986). This method has been widely used on vegetation and phytoplankton data (Varis et al., 1989; Kruk et al., 2002). In order to eliminate any rare taxa present, any species present in fewer than three samples, as well as those that did not amount to at least $2.5 \%$ in at least one sample, were excluded from the analysis. As the distributions were not normalised, the species abundances were transformed into $\log (x+1)$. In order to have equallyweighted results for each month of the annual cycle, the mean reading was used in those cases where two readings were taken in a particular month. Hence, 132 samples (11 stations $\times 12$ months) were considered in this analysis. The ability of environmental variables to explain the variance of the species data in the CCA was tested by performing Monte-Carlo simulations with 1000 unrestricted permutations. As the relative abundances of species were not statistically different among the stations (Friedman ANOVA), the results presented here are based on the average relative abundance calculated from 11 stations on each sampling date. Variables were taken to be significant at $P<0.05$

\section{Results}

\subsection{Temperature, salinity and light conditions}

Salinity was significantly lower in the river mouth than in the rest of the lagoon (Friedman ANOVA, $P<0.001$ ). No significant differences were observed among the other stations (Friedman ANOVA, $P>0.05)$. The changes observed with time in the salinity levels were due to the Mediterranean climate: during June, the total rainfall was less than $20 \mathrm{~mm}$ and the average daily irradiance reached a maximum value of $350 \mathrm{~W} \mathrm{~m}^{-2}$ (Fig 2). Because of increased evaporation and reduced water inputs, the mean salinity increased until August, reaching maximum values of 11.0 in 
the Bolmon lagoon and 18.9 in the Rove canal. At the end of summer, the heavy rainfall typical of the Mediterranean climate resulted in the flooding of the Cadière River, providing the lagoon with direct freshwater inputs which decreased the salinity (Fig. 2). The climatic conditions were found to explain most of the time-related variations in the salinity in the Bolmon lagoon, while the salinity fluctuations in the Rove canal were attributable to the variability of the exchanges with the Berre lagoon: sometimes, strong winds led to salty water inputs from the Berre lagoon, resulting in a peak of salinity in the canal.

Temperature in the lagoon was homogeneous both in the water column and among the stations and paralleled the patterns of irradiance (Fig. 2). The maximum values occurred in August (average value $25.4^{\circ} \mathrm{C}$ ). In winter, the temperatures were lower (average value $c a .4{ }^{\circ} \mathrm{C}$ ), as some parts of the lagoon were covered with ice for a short period during January 2002. The Brunt Väisälä frequency peaked at $4.1 \times 10^{-3} \mathrm{~s}^{-2}$ in June 2002 (not shown).

Light attenuation in the water column was at its maximum in March $2002\left(10 \mathrm{~m}^{-1}\right)$, when the Secchi depth was $15 \mathrm{~cm}$. These parameters were found to be weakly, but significantly, correlated $(r=-$ $0.24 ; P<0.01$ ), in agreement with most previous studies on shallow lakes (Scheffer, 2001). The correlations observed were probably due partly to the fact that scattering has stronger effects on the (inverse) Secchi depth than on the light attenuation, and partly to the composition of the suspended particles.

\subsection{Nutrient dynamics}

DIN and SRP concentrations were high in winter and decreased until March (Fig. 3). The nutrient concentration levels differed among the stations: significantly higher concentrations were recorded in the mouth of the Cadière River than elsewhere (Friedman ANOVA, $P<0,001$ ). By contrast, lower nutrient concentrations were recorded in the canal (S11), probably because of a shorter residence time and a higher water flow. However, the high concentrations of ammonium-N (305 $\mu \mathrm{M}$ in January) observed near the channel communicating with the Rove canal (S6) were probably attributable to the large amounts of domestic sewage originating from dysfunctions of the wastewater processing plant located near the canal. Because of the nitrogen depletion occurring in May in the lagoon, the DIN/SRP ratio was null. In summer, the DIN concentrations remained below $50 \mu \mathrm{M}$ at most of the stations, while the phosphorus content increased (median $=18.5 \mu \mathrm{M})$. The DIN/SRP ratio was then very low in summer (median $=0.4$ in July and median $=1.5$ in August). From September, SRP concentrations decreased sharply (median values were below $2.5 \mu \mathrm{M}$ ), while DIN concentrations increased during autumn (Fig. 3). As a consequence, the DIN/SRP ratio increased at the end of the year and reached the highest median value in December (Fig. 3). 


\subsection{Cyanoprokaryote dominance}

The variation of total phytoplankton abundance was mostly explained by the variations in the cyanoprokaryotes that formed the predominant group all year round. The abundance of this group was always greater than $78 \%$ of the phytoplankton and exceeded $90 \%$ most part of the year (Fig. 4). Among the 18 planktonic species of cyanoprokaryotes identified, 11 belonged to the order of the Chroococcales, 6 to the Oscillatoriales and 1 to the Nostocales (Table I).

During winter and early spring, Planktothrix agardhii was the most numerous species, accounting for more than $90 \%$ of all the phytoplankton until April. A change in the dominance pattern was observed in late spring, when other cyanoprokaryotes became more numerous, reaching abundances ranging from $34 \%$ of the total phytoplankton in May to $65 \%$ in June (Fig. 4). In late autumn, the relative abundance of $P$. agardhii increased because of the decline of other cyanoprokariotic and eukaryotic species (Fig. 4).

Among eukaryotic algae encountered during the study, the most frequently abundant species were small green algae (Monoraphidium spp.), present at all seasons, and the diatom Cylindrotheca closterium. This diatom formed blooms with the small dinoflagellate Heterocapsa rotundata (formerly Katodinium rotundatum) in spring and autumn (unpublished data). In summer, small centric diatoms (Cyclotella spp.) were particularly abundant in the algal assemblage but their number was relatively low compared to cyanoprokaryotes.

\subsection{Pattern of species succession}

A typical succession characterised by $P$. agardhii - Chroococcales - Pseudanabaenaceae $-P$. agardhii emerged from the abundance data (Figs. 4) and biomass composition (Fig. 5). During winter and early spring, Planktothrix agardhii was practically the only cyanoprokaryote species present, and the abundance peak occurring in March was entirely due to its proliferation (Fig. 4). In late spring, the decline of the P. agardhii population coincided with the development of the Chroococcales species, consisting mainly of Aphanocapsa delicatissima, Aphanothece minutissima and Merismopedia tenuissima, which peaked in May and June, when they dominated the phytoplankton assemblage. The sole Nostocale species, Anabaenopsis elenkinii, appeared at this period, but reached only quite low abundances and never exceeded $0.52 \%$ of the mean value obtained at all the stations. In summer, the Chroococcales (A.minutissima, A. delicatissima, $M$. tenuissima) and Oscillatoriales (Pseudanabaena limnetica and P. agardhii) dominated the phytoplankton community. A sharp decrease in the total phytoplankton abundance was observed between July and August, which was mainly due to the decrease of the A. minutissima population. At two stations, S1 and S2, Synechocystis aquatilis proliferated in the early summer, reaching up to 
93.8 \% of the total phytoplankton assemblage at these stations (Table I), but this species was practically absent from the other parts of the lagoon. In late summer and early autumn,

Geitlerinema amphibium and Planktolyngbya limnetica developed at all the stations of the lagoon without becoming dominant, and these species soon decreased. In August, Phormidium sp. was found with typically marine phytoplankton species in the Rove canal (S11, Table I), but was not detected anywhere in the Bolmon lagoon itself. At the end of the annual cycle, all the species except $P$. agardhii decreased from autumn and Planktothrix remained almost the unique species during the cold period (Fig. 4).

Despite the variations in cyanoprokaryote biomass composition, no change in dominance occurred. Because of its larger cell dimensions, Planktothrix agardhii was always greater than $78 \%$ of the total cyanoprokaryotes while other small species were less abundant in biomass (Fig. 5).

\subsection{Correlations with environmental parameters}

Canonical correspondence analysis (CCA) on the 12 most abundant species and 12 physical and chemical parameters (Table II) performed on the set of 132 samples showed the existence of correlations between the pattern of succession and the environmental parameters. The inertia of the CCA was 0.54 and accounted for $43 \%$ of the unconstrained inertia, which means that $43 \%$ of the variability of the species abundance can be explained by the 12 constraining parameters. The eigenvalues on the first two axis ( $\lambda_{1}=0.277$ and $\lambda_{2}=0.165$, respectively) accounted for $82 \%$ of the constrained inertia and a Monte Carlo permutation test ( $n=1000$ permutations) indicated that these eigenvalues were highly significant $(P<0.001)$, which validates the use of this method. The first axis was weighted mainly by irradiance $(r=0.72)$, the Brunt-Väisälä frequency $(r=0.32)$, SRP $(r=$ $0.23)$, and DIN:SRP ratio $(r=-0.25)$. The second CCA axis was strongly correlated with temperature $(r=0.87)$, irradiance $(r=0.59)$, alkalinity $(r=-0.50)$, and nitrate concentration $(r=$ -0.32). Species and environmental variables featured on the same CCA ordination biplot (Fig. 6), where the species associations and the seasonal variations in the composition of the cyanoprokaryote community clearly emerge. At the positive end of axis 1 , species that mostly occurred at the end of spring and at the beginning of summer (L. planctonica, A. delicatissima, C. minimus, A. elenkinii, A. minutissima) correlated with the increasing irradiance and water column stability $\left(N^{2}\right)$. In this shallow lagoon, strong irradiance levels and very calm conditions are required for any stratification to develop, and these conditions were present only in May and June, since the summer was too windy. M. tenuissima and P. limnetica, which occurred in summer, were positively correlated with temperature and salinity, and negatively with alkalinity. S. aquatilis was present at only two stations (S1 and S2), where it bloomed in summer. These very shallow channels were cut 
off from the Berre lagoon during the summer period to stop the exchanges of water with the lagoon because of water sport activities. The warm temperatures (up to $28^{\circ} \mathrm{C}$ ) characteristic of these stations account for the particular pattern of succession shown by this species and its position in the canonical plot. Late summer and autumn species associations were negatively correlated with the first axis, while none of the environmental variables tested were correlated with this side. $A$. clathrata, G. amphibium and Planktolyngbya limnetica showed the strongest negative correlations with SRP. These species were found only during a short period, which explains their outlying position in the biplot.

P. agardhii is the only species that was negatively correlated with both CCA axes, and positively with nitrate and SRP concentrations and water alkalinity. This species was present all year round in all the species associations (Figs. 4, 5); its position in this ordination plot showed the occurrence of changes in the relative abundance of this species among the cyanoprokaryotes. P. agardhii seems to constitute a "monoculture" under low temperature $(r=-0.23, P<0.01)$ and at low DIN/SRP ratios $(r$ $=-0.40, P<0.001)$. The weak correlation observed between the underwater light climate (i.e. $E D$ ) and axis 1 is not surprising, since poor light conditions were observed all year round in this lagoon and these conditions are therefore not likely to be a decisive factor contributing to the changes in the species composition. However, the abundance of dominant Oscillatoriales species responded differently to the mixing conditions and underwater light climate (D/Zs ratio); the abundance of $P$. agardhii was weakly correlated with the D/Zs ratio $(r=0.23 ; P<0.01)$, while $P$. limnetica was negatively correlated $(r=-0.19 ; P<0.05)$.

Planktothrix agardhii abundance was negatively correlated with salt concentration in water $(r=$ -0.68, $P<0.001)$ contrary to Pseudanabaena limnetica $(r=0.23, P<0.01)$. No significant relationship has been found between other species and this factor. Planktothrix was present in almost all the samples but with highest abundances (>10 ${ }^{9}$ cells $\left.1^{-1}\right)$ at salinities between 3.1 and 7.1 (median 5.2), which corresponds to oligo-mesohaline conditions. Pseudanabaena has been found in a wide range of salinities (from 1.8 to 23.5$)$ but it reached highest abundances $\left(>10^{8}\right.$ cells $1^{-1}$ ) between 3.3 and 9.4 (median 6.5).

\section{Discussion}

Proliferations of cyanoprokaryotes commonly occur under eutrophic conditions in fresh and brackish ecosystems at all latitudes, but the composition of species generally differs between these habitats because of the salinity (Paerl, 1988b, 1996). In eutrophic brackish waters and lagoons, blooms of cyanoprokaryotes generally consist of picoplanktonic species, such as Synechococcus sp. (Phlips et al., 1999; Sorokin et al., 2004) or colonial forms like Aphanothece sp., Anabaenopsis sp., 
Aphanizomenon sp. and Nodularia sp. (Moss, 1994; Kanoshina et al., 2003; Gasiūnaitè et al., 2005). By contrast, filamentous and non heterocytous species (Oscillatoriales) are typical blooming species in polluted and shallow freshwater lakes, mostly in the northern temperate area (e.g. Willén and Mattsson, 1997; Whitton and Potts, 2000; Briand et al., 2002; Mischke, 2003). This study from the Bolmon lagoon brings three original results: 1) a continuous dominance of Oscillatoriales in a Mediterranean lagoon, 2) a salinity tolerance of the species and 3) an atypical succession pattern of cyanoprokaryotes.

\subsection{Success of Oscillatoriales in the Mediterranean area}

Only a few studies report the success of filamentous cyanoprokaryotes in a Mediterranean climate (Romo and Miracle, 1993; Rojo and Alvarez Cobelas, 1994). In the Bolmon lagoon, as in most of the Planktothrix-dominated lakes, the hypereutrophic state and an excess of nutrient, especially phosphorus, are likely to explain the success of Oscillatoriales. As shown by field studies (Berger, 1975; Schindler, 1977; Niemi, 1979; Romo and Miracle, 1993) and experiments (Ahlgren, 1985), the excess of phosphorus and the resulting low N:P atomic ratio (i.e. <16; Redfield, 1958) in the lagoon seem to favour the growth of Planktothrix agardhii. In our study, high SRP concentrations throughout the year probably explain the proliferation of this species. Abundant phosphorus stimulates phytoplankton growth that indirectly leads to a decrease of light penetration in water. Turbidity and available phosphorus consequently favours Oscillatoriales dominance since it is now established that light limitation is a key factor responsible for their development (Zevenboom et al., 1982; Berger, 1984; Scheffer et al., 1997). Experimental data have shown that the growth of $P$. agardhii requires low light intensities (Foy et al., 1976), and field observations have suggested that paradoxically, the self-shading caused by the increasing waterborne biomass may have positive effects on the growth of Planktothrix (Zevenboom et al., 1982; Berger, 1984). According to the bistability model proposed by Scheffer et al. $(1993 ; 1997)$ for shallow lakes, the Bolmon lagoon has shifted to the 'turbid stable state' characterised by the dominance of cyanoprokaryotes. The high level of vertical light attenuation in the lagoon is probably one of the main factors which contributed to the shift to the Oscillatoriales dominance and allow them to persist, although interactions with other factors may occur. For instance, shallowness predisposes this lagoon to turbulent mixing by wind and subsequent sediment resuspension, which increase both the background turbidity and the nutrient content of the water (Padisák and Reynolds, 2003). Owing to the frequent mixing of the water column, the Oscillatoriales periodically undergo short periods in the euphotic layer, sufficient for their photosynthesis. Hence mixing allows them to compensate for the low light penetration in water. From a functional point of view, the most successful species in 
this turbid environment ( $P$. agardhii in winter and spring, and $P$. limnetica in summer) both belong to the $\mathrm{S} 1$ functional type, defined for species adapted to mixed water columns and low average illumination in Reynolds' classification (Reynolds, 1980; Reynolds et al., 2002). Sediment resuspension also allows for the release of filaments into the water column and probably results in frequent inoculations of these species. This may explain the persistence of this assemblage in the saline lagoon.

\subsection{Tolerance of the species to salinity}

Nowadays, Planktothrix agardhii is considered as a typical freshwater species (Komárek and Anagnostidis, 2005), while early in the twentieth century it was classified as a 'halophyte' species (Välikangas, 1926 in Remane and Schlieper, 1971). Since this record in the Baltic Sea, blooms of $P$. agardhii have been very little reported in oligohaline brackish areas (Niemi, 1973; Alasaarela, 1979; Niemi, 1979; Persson, 1981, 1985; Romo and Miracle, 1993). However, compared with these ecosystems, the conductivity in the Bolmon lagoon was higher (averaging $8.7 \mathrm{mS} \mathrm{cm}^{-1}$ during the winter-spring period, which corresponds to oligo-mesohaline conditions) (Remane and Schlieper, 1971). The persistence of Oscillatoriales in the Bolmon lagoon throughout the year shows their ability to thrive not only in mesohaline conditions but also with sporadic salinity fluctuations. It is a critical point, since salinity variations can damage the enzymatic complexes involved in the photosynthesis process (e. g. ferredoxin-NADP reductase; Tel-Or and Melamed-Harel, 1981): even very slight changes in the total ionic strength can cause dramatic alterations in the dominance patterns of cyanoprokaryotes (Paerl, 1988b). From this study, the dominant Oscillatoriales $P$. agardhii and Pseudanabaena limnetica can be considered as halotolerant species when their requirements for nutrients, light and mixing are satisfied. However, the decrease of Planktothrix population at highest salinities in summer suggests that $P$. limnetica is probably more competitive and more halophytic than $P$. agardhii under these conditions.

\subsection{Seasonal succession of cyanoprokaryotes and relationship with environmental factors}

In northern Europe, filamentous cyanoprokaryotes generally dominate the phytoplankton in late summer and decline during the cold period (van Liere and Mur, 1980; Berger and Sweers, 1988; Rojo and Alvarez Cobelas, 1994; Mischke, 2003).In contrast, in the Bolmon lagoon the seasonal succession of $P$. agardhii - Chroococcales - Pseudanabaenacae - P. agardhii is remarkably similar to that described in the Albufera hypereutrophic lagoon in Spain where Planktothrix remained abundant in winter and peaked in spring (Romo and Miracle, 1993). In northern lakes, cold winter temperatures can be detrimental and interrupt the perennial dominance by Planktothrix (Berger, 
1975; Scheffer et al., 1997), while the winter mildness in the Mediterranean area allows the survival of $P$. agardhii and promotes its earlier vernal growth.

Intense growth of $P$. agardhii in spring induced a nutrient depletion in late spring that favoured the heterocytous nitrogen-fixing species Anabaenopsis elenkinii, which is more competitive at limiting nitrogen concentrations. This species has high requirements for light and warmth as the formation of heterocytes implies intense photosynthesis (Dokulil and Teubner, 2000). This explains its presence only in early summer, as in the Albufera (Romo and Miracle, 1994), but the low light availability in the water column probably induced a rapid decline of the Nostocales in summer (Zevenboom and Mur, 1980). In June-July, strong irradiance associated with calm conditions can induce very short periods of relative vertical stability (Padisák and Reynolds, 2003) which is favourable to the development of certain Chroococcales species. These include mainly Aphanocapsa delicatissima, Aphanothece minutissima and Merismopedia tenuissima, as reported in a mesocosm experiment in the Albufera (Romo et al., 2004), which belong to the functional type K and are generally associated with short, nutrient-rich columns (Reynolds et al., 2002). This agrees with the conditions pertaining in the lagoon at this period.

The presence of Limnothrix planctonica is of particular interest as another species of the genus, $L$. redekei Meffert, commonly occurs together with P. agardhii in freshwater temperate lakes. However, L. redekei generally dominates in spring and precedes Planktothrix in the succession pattern (Berger and Sweers, 1988; Rücker et al., 1997; Briand et al., 2002; Mischke, 2003). By contrast, the occurrence of L. planctonica after the P. agardhii maximum, in late spring and summer, seems to be specific to the Mediterranean area, as observed by Rojo and Alvarez Cobelas (1994) in the shallow lake of El Porcal. In the Bolmon lagoon, L. planctonica was present only for a short period, when both nitrogen and phosphorus were depleted because of the development of $P$. agardhii. Then, L. planctonica was rapidly displaced by Pseudanabaena limnetica in summer. These genera are taxonomically very similar (Meffert, 1988) and seem to have similar low-light and mixing requirements. The mechanisms involved in the succession of these low-light adapted members of the $\mathrm{S} 1$ group have not yet been completely explained. Competition experiments carried out on P. agardhii and L. redekei showed that high irradiance, high temperature and long photoperiod favoured either the dominance of L. redekei or the coexistence of both species under unlimited nutrient levels (Nicklisch et al., 1991). This is in agreement with the present study. Rücker et al. (1997) observed that L. redekei occurred in lakes where stratification was more frequent and suggested that a lower SRP content and less light may favour $L$. redekei over $P$. agardhii. In the Bolmon lagoon, L. planctonica occurred at low SRP concentrations, and this species may have the same nutrient requirements as L. redekei, unlike Pseudanabaena limnetica 
that was found at high phosphorus concentrations. Pseudanabaena species (mainly P. limnetica) are commonly observed among the summer phytoplankton in European lakes (Rojo and Alvarez Cobelas, 1994; Mischke, 2003) but they are rarely dominant. Strong mixing induced by wind and high irradiance levels during summer are probably detrimental to the less tolerant species. In our study, P. limnetica was the most successful species in the S1 group under conditions of high surface irradiance, which is in agreement with the pattern of dominance observed in other Mediterranean areas where Pseudanabaena galeata have been found to dominate in early summer and codominate with P. agardhii in autumn (Romo and Miracle, 1993). It is remarkable to observe a quite similar late-summer composition of Geitlerinema amphibium, Planktolyngbya limnetica and to a lesser extent Aphanothece clathrata in the Bolmon lagoon and the Albufera (Romo and Miracle, 1993, 1994). In both lagoons, these species were correlated with low phosphorus concentrations. In the warmer Spanish lagoon, Geitlerinema sp., a species that stores intracellular phosphorus, was able to dominate the summer population because SRP depletion generally occurred in early summer. By contrast, G. amphibium appeared later in the Bolmon lagoon since phosphorus did not reduce before September. Moreover, as the phosphorus depletion period was rather short in this lagoon, $G$. amphibium population was rapidly replaced by Planktothrix and Pseudanabaena in October, as reported in the Albufera (Romo and Miracle, 1993).

In conclusion, this study shows that dominance by filamentous cyanoprokaryotes, extensively reported in eutrophic shallow lakes from the northern temperate area, can also occurs in brackish lagoons of the south-temperate region in cases of extreme eutrophication. Most of the species described here are usually known from freshwater and this study provides new data about their ecology and halotolerance. The typical succession pattern observed in the Bolmon lagoon and the Albufera of Valencia suggests that the mild winter and hot summer typical of the Mediterranean climate may modify the patterns observed at higher latitudes. However, complementary studies of similar eutrophic brackish lagoons from various locations with a similar climate are required to ascertain this hypothesis.

\section{Acknowledgements}

The authors wish to thank Cécile Claret for her numerous comments and improvements of the paper, Peter Webber for kindly accepting to revise the English manuscript; three anonymous referees and D.S. McLusky for their comments and suggestions on this paper. This study was funded by the Provence-Alpes-Côte-d'Azur Regional Council and the Public Interest Group for the Berre lagoon Rehabilitation (GIPREB). 


\section{References}

Abrantes, N., Antunes, S. C., Pereira, M. J. and Gonçalves, F., 2006. Seasonal succession of cladocerans and phytoplankton and their interactions in a shallow eutrophic lake (Lake Vela, Portugal). Acta Oecologica 29, 54-64.

AFNOR, 1979. Recueil de normes françaises. Eaux. Méthodes d'essai, AFNOR, Paris, 342 pp.

Ahlgren, G., 1985. Growth of Oscillatoria agardhii in chemostat culture 3. Simultaneous limitation of nitrogen and phosphorus. British Phycological Journal 20, 249-261.

Alasaarela, E., 1979. Spatial, seasonal and long-term variations in the phytoplanktonic biomass and species composition in the coastal waters of the Bothnian Bay off Oulu. Annales Botanici Fennici $16,108-122$.

Anagnostidis, K. and Komárek, J., 1985. Modern approach to the classification system of cyanophytes. 1 - Introduction. Algological Studies 38-39, 291-302.

Anagnostidis, K. and Komárek, J., 1988. Modern approach to the classification system of cyanophytes. 3 - Oscillatoriales. Algological Studies 50-53, 327-472.

Barica, J. and Mur, L. R., 1980. Hypertrophic ecosystems - Development in hydrobiology Vol. 2, DR. W. Junk BV, The Hague, 347 p.

Barnes, R. S. K., 1980. Coastal lagoons (Cambridge Studies in Modern Biology 1), Cambridge University Press, Cambridge, 106 pp.

Bazaïri, H., Bayed, A., Glémarec, M. and Hily, C., 2003. Spatial organisation of macrozoobenthic communities in response to environmental factors in a coastal lagoon of the NW African coast (Merja Zerga, Morocco). Oceanologica Acta 26, 457-471.

Berger, C., 1975. Occurence of Oscillatoria agardhii Gom. in some shallow eutrophic lakes. Verhandlungen die internationale Vereinigung für theoretische und angewandte Limnologie 19, 2689-2697. 
Berger, C., 1984. Consistent blooming of Oscillatoria agardhii Gom. in shallow hypertrophic lakes. Verhandlungen die internationale Vereinigung für theoretische und angewandte Limnologie 22, 910-916.

Berger, C. and Sweers, H. E., 1988. The IJsselmeer and its phytoplankton - with special attention to the suitability of the lake as a habitat for Oscillatoria agardhii Gom. Journal of Plankton Research 10, 579-599.

Boutière, H., 1974. L'étang de Bages-Sigean, modèle de lagune méditerranéenne. Vie et Milieu 24, 23-58.

Briand, J.-F., Robillot, C., Quiblier-Llobéras, C. and Bernard, C., 2002. A perennial bloom of Planktothrix agardhii (Cyanobacteria) in a shallow eutrophic French lake: limnological and microcystin production studies. Archiv für Hydrobiologie 153, 605-622.

Cloern, J. E., 2001. Our evolving conceptual model of the coastal eutrophication problem. Marine Ecology Progress Series 210, 235-265.

Codd, G. A., 2000. Cyanobacterial toxins, the perception of water quality, and the prioritisation of eutrophication control. Ecological Engineering 16, 51-60.

Dokulil, M. T. and Teubner, K., 2000. Cyanobacterial dominance in lakes. Hydrobiologia 438, 112.

European Union, 2000. Directive 2000/60/EC of the European Parliament and of the Council of 23 October 2000 establishing a framework for the Community action in the field of water policy. Official Journal L 327, 1-73.

Foy, R. H., Gibson, C. E. and Smith, R. V., 1976. The influence of daylength, light intensity and temperature on the growth rates of planktonic blue-green algae. British Phycological Journal 11, 151-163.

Gasiūnaitè, Z. R., Cardoso, A. C., Heiskanen, A.-S., Henriksen, P., Kauppila, P., Olenina, I., Pilkaitytė, R., Purina, I., Razinkovas, A., Sagert, S., Schubert, H. and Wasmund, N., 2005. Seasonality of coastal phytoplankton in the Baltic Sea: influence of salinity and eutrophication. Estuarine, Coastal and Shelf Science 65, 239-252. 
Harzallah, A. and Chapelle, A., 2002. Contribution of climate variability to occurences of anoxic crises 'malaïgues' in the Thau lagoon (southern France). Oceanologica Acta 25, 79-86.

Healy, B., 1997. Long-term changes in a brackish lagoon, Lady's Island Lake, South-East Ireland. Proceedings of the Royal Irish Academy (Biology and Environment) 97B, 33-51.

Kanoshina, I., Lips, U. and Leppänen, J.-M., 2003. The influence of weather conditions (temperature and wind) on cyanobacterial bloom development in the Gulf of Finland (Baltic Sea). Harmful algae 2, 29-41.

Komárek, J. and Anagnostidis, K., 1999. Süßwasserflora von Mitteleuropa. Band 19/1.

Cyanoprokaryota 1. Teil: Chroococcales, Spektrum Akademischer Verlag, Heidelberg, Berlin, 548 pp.

Komárek, J. and Anagnostidis, K., 2005. Süßwasserflora von Mitteleuropa. Band 19/2. Cyanoprokaryota 2. Teil: Oscillatoriales, Elsevier - Spektrum Akademisher Verlag, Munich, 759 pp.

Kruk, J., Mazzeo, N., Lacerot, G. and Reynolds, C. S., 2002. Classification schemes for the phytoplankton: a local validation of a functional approach to the analysis of species temporal replacement. Journal of Plankton Research 24, 901-912.

Loureiro, S., Newton, A. and Icely, J., 2006. Boundary conditions for the European Water Framework Directive in the Ria Formosa lagoon, Portugal (physico-chemical and phytoplankton quality elements). Estuarine, Coastal and Shelf Science 67, 382-398.

Mackereth, F. J. H., Heron, J. and Talling, J. F., 1978. Water analysis : some revised methods for limnologists, Freshwater Biological Association Scientific publication no. 36, 120 pp.

McCutcheon, S. C., Martin, J. L. and Barnwell, T. O. J., 1993. Water quality. In: Maidment, D. R. (ed.) Handbook of hydrology. McGraw-Hill, New York, chap. 11.

Meffert, M.-E., 1988. Limnothrix Meffert nov. gen. The unsheathed planktic cyanophycean filaments with polar and central gas vacuoles. Algological Studies 50-53, 269-276. 
Menéndez, M. and Comin, F. A., 2000. Spring and summer proliferation of floating macroalgae in a Mediterranean coastal lagoon (Tandcada Lagoon, Ebro Delta, NE Spain). Estuarine, Coastal and Shelf Science 51, 215-226.

Mischke, U., 2003. Cyanobacteria associations in shallow polytrophic lakes: influence of environmental factors. Acta Oecologica 24, S11-S23.

Moss, B., 1994. Brackish and freshwater shallow lakes - different systems or variations on the same theme? Hydrobiologia 275/276, 1-14.

Nicklisch, A., Roloff, B. and Ratsch, A., 1991. Competition experiments with two planktic bluegreen algae (Oscillatoriaceae). Verhandlungen die internationale Vereinigung für theoretische und angewandte Limnologie 24, 889-892.

Niemi, Å., 1973. Ecology of phytoplankton in the Tvärminne area, SW coast of Finland. I. Dynamics of hydrography, nutrients, chlorophyll $a$ and phytoplankton. Acta Botanica Fennica 100, $1-68$.

Niemi, Å., 1979. Blue-green algal blooms and N : P ratio in the Baltic sea. Acta Botanica Fennica $110,57-61$.

Nixdorf, B., 1994. Polymixis of a shallow lake (Großer Müggelsee, Berlin) and its influence on seasonal phytoplankton dynamics. Hydrobiologia 275/276, 173-186.

Oksanen, J., 2005. vegan: Community Ecology Package. R package version 1.6-7. http://cc.oulu.fi/ jarioksa/

Padisák, J. and Reynolds, C. S., 2003. Shallow lakes: the absolute, the relative, the functional and the pragmatic. Hydrobiologia 506-509, 1-11.

Paerl, H. W., 1988a. Nuisance phytoplankton blooms in coastal, estuarine, and inland waters. Limnology and Oceanography 33, 823-847.

Paerl, H. W., 1988b. Growth and reproductive strategies of freshwater blue-green algae (cyanobacteria). In: Sandgren, C. D. (ed.) Growth and reproductive strategies of freshwater phytoplankton. University Press, Cambridge, pp. 261-315. 
Paerl, H. W., 1996. A comparison of cyanobacterial bloom dynamics in freshwater, estuarine and marine environments. Phycologia 35, 25-35.

Pastres, R., Solidoro, C., Ciavatta, S., Petrizzo, A. and Cossarini, G., 2004. Long-term changes of inorganic nutrients in the Lagoon of Venice (Italy). Journal of Marine Systems 51, 179-189.

Persson, P.-E., 1981. Growth of Oscillatoria agardhii in a hypertrophic brackish-water bay. Ann. Bot. Fennici 18, 1-12.

Persson, P.-E., 1985. Phytoplankton dynamics in a hypertrophic brackish-water bay. Verhandlungen die internationale Vereinigung für theoretische und angewandte Limnologie 22, 2203-2207.

Phlips, E. J., Badylak, S. and Lynch, T. C., 1999. Blooms of the picoplanktonic cyanobacterium Synechococcus in Florida Bay, a subtropical inner-shelf lagoon. Limnology and Oceanography 44, 1166-1175.

R Development Core Team, 2004. R: A language and environment for statistical computing. 2.01. http://www.R-project.org

Redfield, A. C., 1958. The biological control of chemical factors in the environment. American Scientist 46, 205-221.

Remane, A. and Schlieper, C., 1971. Biology of brackish water. In: Elster, H.-J. and Ohle, W. (eds), Die Binnengewässer (vol. XXV). E. Schweizerbart'sche Verlagsbuchhandlung, Stuttgart, pp. 372.

Reynolds, C. S., 1980. Phytoplankton assemblages and their periodicity in stratifying lake systems. Holarctic ecology 3, 141-159.

Reynolds, C. S., 1987. Cyanobacterial water-blooms. Advances in Botanical Research 13, 67-143.

Reynolds, C. S., Huszar, V. L. M., Kruk, J., Naselli-Flores, L. and Melo, S., 2002. Towards a functional classification on the freshwater phytoplankton. Journal of Plankton Research 24, 417428. 
Rojo, C. and Alvarez Cobelas, M., 1994. Population dynamics of Limnothrix redekei, Oscillatoria lancaeformis, Planktothrix agardhii and Pseudanabaena limnetica (cyanobacteria) in a shallow hypertrophic lake (Spain). Hydrobiologia 275/276, 165-171.

Romo, S. and Miracle, M. R., 1993. Long term periodicity of Planktothrix agardhii, Pseudanabaena galeata and Geitlerinema sp. in a shallow hypertrophic lagoon, the Albufera of Valencia (Spain). Archiv für Hydrobiologie 126, 469-486.

Romo, S. and Miracle, M. R., 1994. Population dynamics and ecology of subdominant phytoplankton species in a shallow hypertrophic lake (Albufera of Valencia, Spain). Hydrobiologia 273, 37-56.

Romo, S., Miracle, M. R., Villena, M. J., Rueda, J., Ferriol, C. and Vicente, E., 2004. Mesocosm experiments on nutrient and fish effects on shallow lake food webs in a Mediterranean climate. Freshwater Biology 49, 1593-1607.

Rücker, J., Wiedner, C. and Zippel, P., 1997. Factors controlling the dominance of Planktothrix agardhii and Limnothrix redekei in eutrophic shallow lakes. Hydrobiologia 342/343, 107-115.

Scheffer, M., Hosper, S. H., Meijer, M.-L., Moss, B. and Jeppesen, E., 1993. Alternative equilibria in shallow lakes. Trends in Ecology and Evolution 8, 275-279.

Scheffer, M., Rinaldi, S., Gragnani, A., Mur, L. R. and van Nes, E. H., 1997. On the dominance of filamentous cyanobacteria in shallow, turbid lakes. Ecology 78, 272-282.

Scheffer, M., 2001. Ecology of shallow lakes (2nd ed.), Kluwer Academic, Dordrecht, 357 pp.

Schindler, D. W., 1977. Evolution of phosphorus limitation in lakes. Science 195, 260-262.

Sokal, R. R. and Rholf, F. J., 2000. Biometry. The principle and practice of statistics in biological research., W.H. Freeman and company, New York, 887 pp.

Sorokin, P. Y., Sorokin, Y. I., Boscolo, R. and Giovanardi, O., 2004. Bloom of picocyanobacteria in the Venice lagoon during summer-autumn 2001: ecological sequences. Hydrobiologia 523, 71-85. 
Sun, J. and Liu, D., 2003. Geometric models for calculating cell biovolume and surface area for phytoplankton. Journal of Plankton Research 25, 1331-1346.

Tel-Or, E. and Melamed-Harel, H., 1981. Adaptation to salt of the photosynthetic apparatus in cyanobacteria. In: Akoyunoglou, G. (ed.) Photosynthesis VI. Photosynthesis and productivity, Photosynthesis and environment. Balaban International, Philadelphia, pp. 455-462.

Ter Braak, C. J. F., 1986. Canonical correspondence analysis: a new eigenvector technique for multivariate direct gradient analysis. Ecology 67, 1167-1179.

Thioulouse, J., Dufour, A.-B. and Chessel, D., 2004. ade4: Analysis of Environmental Data : Exploratory and Euclidean methods in Environmental sciences. R package version 1.3-3. http://pbil.univ-lyon1.fr/ADE-4

Utermöhl, H., 1958. Zur Vervollkommung der quantitativen Phytoplankton - Methodik. Mitteilung der internationale Vereinigung für Limnologie 9, 1-39.

van de Bund, W., Romo, S., Villena, M. J., Valentin, M., van Donk, E., Vicente, E., Vakkilainen, K., Svensson, M., Stephen, D., Stahl-Delbanco, A., Rueda, J., Moss, B., Miracle, M. R., Kairesalo, T., Hansson, L.-A., Hietala, J., Gyllström, M., Goma, R. H., Garcia, P., Fernandez-Alaez, M., Fernandez-Alaez, C., Ferriol, C., Collings, S. E., Bécares, E., Balayla, D. M. and Alfonso, T., 2004. Responses of phytoplankton to fish predation and nutrient loading in shallow lakes: a pan-European mesocosm experiment. Freshwater Biology 49, 1608-1618.

van Liere, L. and Mur, L. R., 1980. Occurence of Oscillatoria agardhii and some related species, a survey. In: Barica, J. and Mur, L. R. (eds), Hypertrophic ecosystems. Dr. W. Junk b. v., The Hague, pp. 67-77.

Varis, O., Sirviö, H. and Kettunen, J., 1989. Multivariate analysis of lake phytoplankton and environmental factors. Archiv für Hydrobiologie 117, 163-175.

Vicente, E. and Miracle, M. R., 1992. The coastal lagoon Albufera de Valencia: an ecosystem under stress. Limnética 8, 87-100.

Whitton, B. A. and Potts, M., 2000. The ecology of cyanobacteria. Their diversity in time and space, Kluwer Academic Publishers, Dordrecht, 669 p. 
Willén, T. and Mattsson, R., 1997. Water-blooming and toxin-producing cyanobacteria in Swedish fresh and brackish waters, 1981-1995. Hydrobiologia 353, 181-192.

Zevenboom, W. and Mur, L. R., 1980. $\mathrm{N}_{2}$-fixing cyanobacteria: why they do not become dominant in dutch, hypertrophic lakes. In: Barica, J. and Mur, L. R. (eds), Developments in Hydrobiology vol 2 : Hypertrophic Ecosystems. Dr. W. Junk bv Publishers, The Hague, pp. 123-130.

Zevenboom, W., Bij de Vaate, A. and Mur, L. R., 1982. Assessment of factors limiting growth rate of Oscillatoria agardhii in hypertrophic lake Wolderwijd, 1978, by use of physiological indicators. Limnology and Oceanography 27, 39-52. 


\section{Table and Figure legends:}

Table I: Taxonomy of the eighteen cyanoprokaryote species encountered during the investigation period (year 2002) in the Bolmon lagoon, and mean ( \pm SD) and range of variations (in brackets) of their relative abundance ( $n=132$ samples). Abundances were calculated from cell counts and are relative to the phytoplankton, including eukaryotic algae. The codes used in the CCA refer only to the most abundant species (see text).

Table II. Mean ( \pm SD), minimum and maximum values of selected environmental factors included in the CCA, and codes used in Fig. 6.

Figure 1: Map of the Bolmon lagoon showing its location, bathymetry, sampling sites and connections with other ecosystems (arrows).

Figure 2: Seasonal variations in the main environmental parameters (from top to bottom): mean daily irradiance and mean water temperature on each sampling day $(n=11)$; rainfall; mean salinity in the lagoon $(n=9)$, the river mouth (S7) and the Rove canal (S11); Secchi depth $\left(Z_{s}\right)$ and light extinction $(E)$ during the study period.

Figure 3: Concentrations (A, B) and atomic ratios (C) of dissolved inorganic nitrogen (DIN) and soluble reactive phosphorus (SRP) in the Bolmon lagoon in 2002 ( $n=11$ stations, except for months marked with a dot where $n=22$ ). The dotted line in graph $\mathrm{C}$ corresponds to an atomic $\mathrm{N}: \mathrm{P}$ ratio of 16 . Vertical boxes delimit $1^{\text {st }}$ and $3^{\text {rd }}$ quartile of the data, while median values are represented as horizontal lines. Whiskers delimit the data range.

Figure 4: Seasonal variations in the average phytoplankton abundance showing the proportion of Planktothrix agardhii (filled) and other cyanoprokaryotes (crosses) in the community (A) and variations in the abundance of the main species of other cyanoprokaryotes (B) during the investigation period in the Bolmon lagoon. Data are mean values based on eleven sampling sites.

Figure 5: Seasonal variations in the cyanoprokaryotes biomass composition during the investigation period. Data are mean values based on eleven sampling sites.

Figure 6: Species - environment biplot CCA. The points stand for the individual cyanoprokaryote species and the arrow indicates each of the environmental variables, pointing in the direction of 
maximum change across the diagram during the Bolmon lagoon study. For codes, see Table I for species and Table II for environmental factors. 


\section{Division Cyanoprokaryota}

Class Nostocophyceae (Cyanophyceae)
Relative abundance (\%)

among the phytoplankton

CCA code

Mean \pm SD (min. - max.)

\section{Chroococcales}

Chroococcaceae

Chroococcus minimus (Keissler) Lemmermann

Chroococcus cf. minutus (Kützing) Nägeli

$$
\begin{array}{cc}
0.2 \pm 0.4(0-2.9) & \text { Chro min } \\
0.01 \pm 0.03(0-0.35) & -
\end{array}
$$

Merismopediaceae

Aphanocapsa delicatissima W. et G. S. West

Merismopedia cf. glauca (Ehrenberg) Kützing

Merismopedia tenuissima Lemmermann

Merismopedia sp.1

Merismopedia sp.2

Synechocystis aquatilis Sauvageau

$$
\begin{array}{cc}
3.4 \pm 7.7(0-39.7) & \text { Aph del } \\
0.001 \pm 0.001(0-0.011) & - \\
1.6 \pm 2.8(0-16.0) & \text { Mer ten } \\
0.01 \pm 0.02(0-0.27) & - \\
0.001 \pm 0.001(0-0.016) & - \\
1.1 \pm 9.4(0-93.8) & \text { Syn aqua }
\end{array}
$$

Microcystaceae

Microcystis sp.

$$
0.001 \pm 0.001(0-0.04)
$$

Synechococcaceae

Aphanothece clathrata W. et G.S. West

Aphanothece minutissima Komárková-Legnerová et Cronberg

$$
\begin{array}{ll}
0.05 \pm 0.15(0-0.9) & \text { Aph cla } \\
6.6 \pm 13.8(0-60.3) & \text { Aph min }
\end{array}
$$

\section{Oscillatoriales}

Phormidiaceae

Planktothrix agardhii (Gom.) Anagnostidis et Komárek

Phormidium sp.

$$
\begin{array}{cc}
65.0 \pm 28.6(1.5-98.6) & \text { Plan aga } \\
0.6 \pm 6.5(0-74.2) & -
\end{array}
$$

Pseudanabaenaceae

Limnothrix planctonica Meffert

Pseudanabaena limnetica Böcher

Geitlerinema amphibium (Ag. ex Gom.) Anagnostidis

Planktolyngbya limnetica (Lemm.) Komárková-Legnerová et Cronberg

$$
\begin{array}{cc}
0.5 \pm 1.8(0-11.2) & \text { Limn pla } \\
7.7 \pm 11.4(0-40.6) & \text { Pse lim } \\
0.6 \pm 1.7(0-12.3) & \text { Geit amp } \\
0.5 \pm 3.0(0-33.8) & \text { Plan lim }
\end{array}
$$

\section{Nostocales}

Nostocaceae

Anabaenopsis elenkinii Miller

$0.01 \pm 0.05(0-6.6)$

Ana elen 


\begin{tabular}{lcccc}
\hline \hline Environmental factor & $\begin{array}{c}\text { CCA } \\
\text { Code }\end{array}$ & Mean \pm SD & Minimum & Maximum \\
\hline Temperature $\left({ }^{\circ} \mathrm{C}\right)$ & $\mathrm{T}$ & $16.2 \pm 6.5$ & 5.2 & 27.4 \\
Irradiance $\left(\right.$ monthly average, $\left.\mathrm{Wm}^{-2}\right)$ & $\mathrm{I}$ & $211.4 \pm 116.9$ & 46.3 & 376.2 \\
Salinity & $\mathrm{Salin}$ & $6.0 \pm 2.9$ & 1.4 & 23.5 \\
Brunt-Väisälä frequency $\left(\times 10^{-3} \mathrm{~s}^{-2}\right)$ & $\mathrm{N}^{2}$ & $0.26 \pm 1.27$ & 0.01 & 4.15 \\
underwater light climate & $\mathrm{ED}$ & $8.4 \pm 3.3$ & 2.9 & 25.5 \\
pH & $\mathrm{pH}$ & $8.3 \pm 0.8$ & 6.0 & 9.6 \\
Alkalinity $\left(\right.$ meq $\left.\mathrm{L}^{-1}\right)$ & $\mathrm{Alk}$ & $3.7 \pm 0.6$ & 2.5 & 5.6 \\
Nitrate $(\mu \mathrm{M})$ & $\mathrm{NO}_{3}$ & $23.0 \pm 33.6$ & 0 & 140.3 \\
Nitrite $(\mu \mathrm{M})$ & $\mathrm{NO}_{2}$ & $2.0 \pm 3.1$ & 0 & 23.9 \\
Ammonium $(\mu \mathrm{M})$ & $\mathrm{NH}_{4}$ & $16.8 \pm 32.4$ & 0 & 160.8 \\
Dissolved inorganic nitrogen $(\mu \mathrm{M})$ & $\mathrm{DIN}$ & $41.9 \pm 60.9$ & 0 & 397.5 \\
Soluble reactive phosphorus $(\mu \mathrm{M})$ & $\mathrm{SRP}$ & $6.0 \pm 5.7$ & 0.1 & 24.3 \\
DIN:SRP atomic ratio & $\mathrm{N}: \mathrm{P}$ & $17.0 \pm 39.9$ & 0 & 260.9 \\
\hline \hline
\end{tabular}




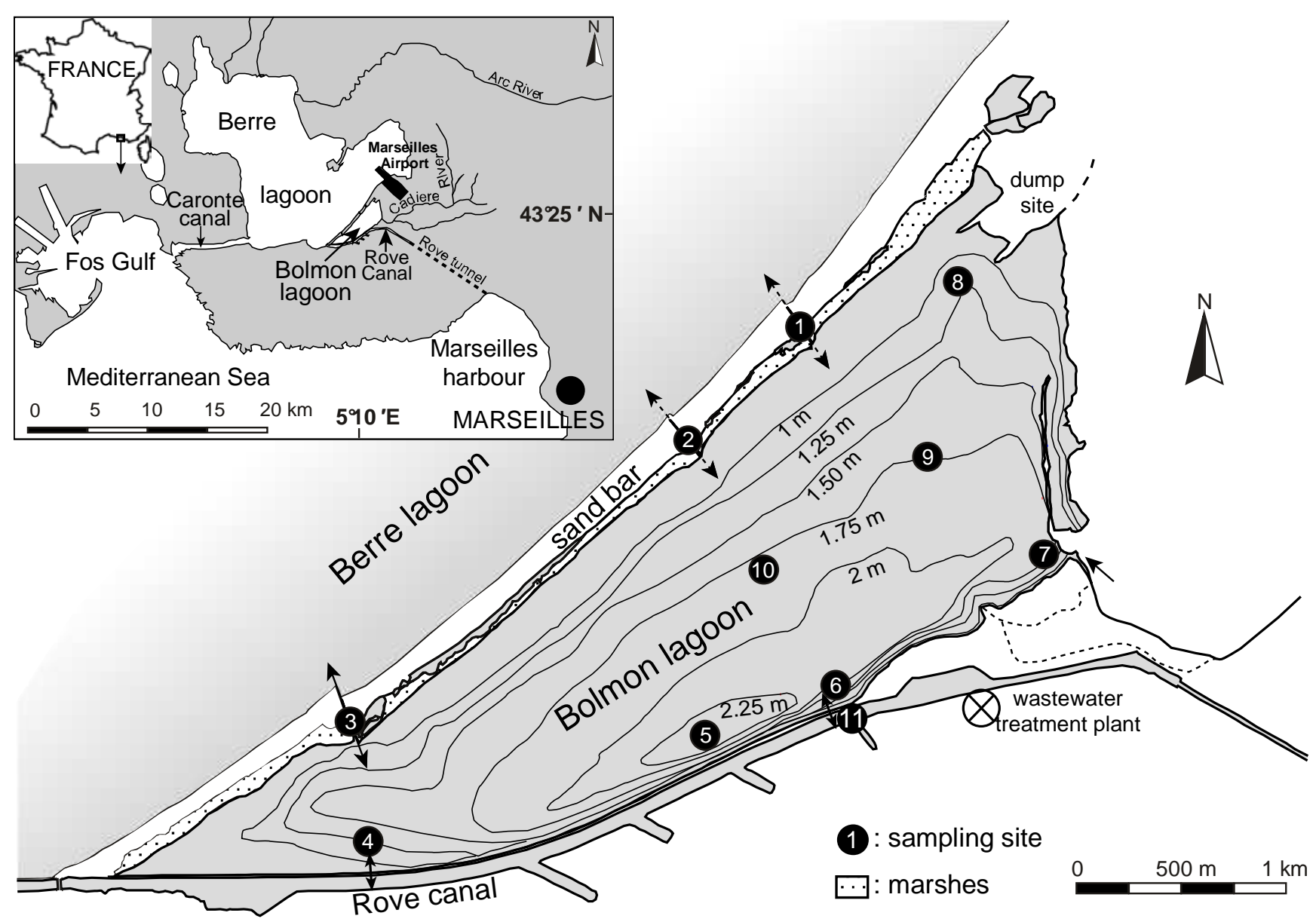

Fig. 1 


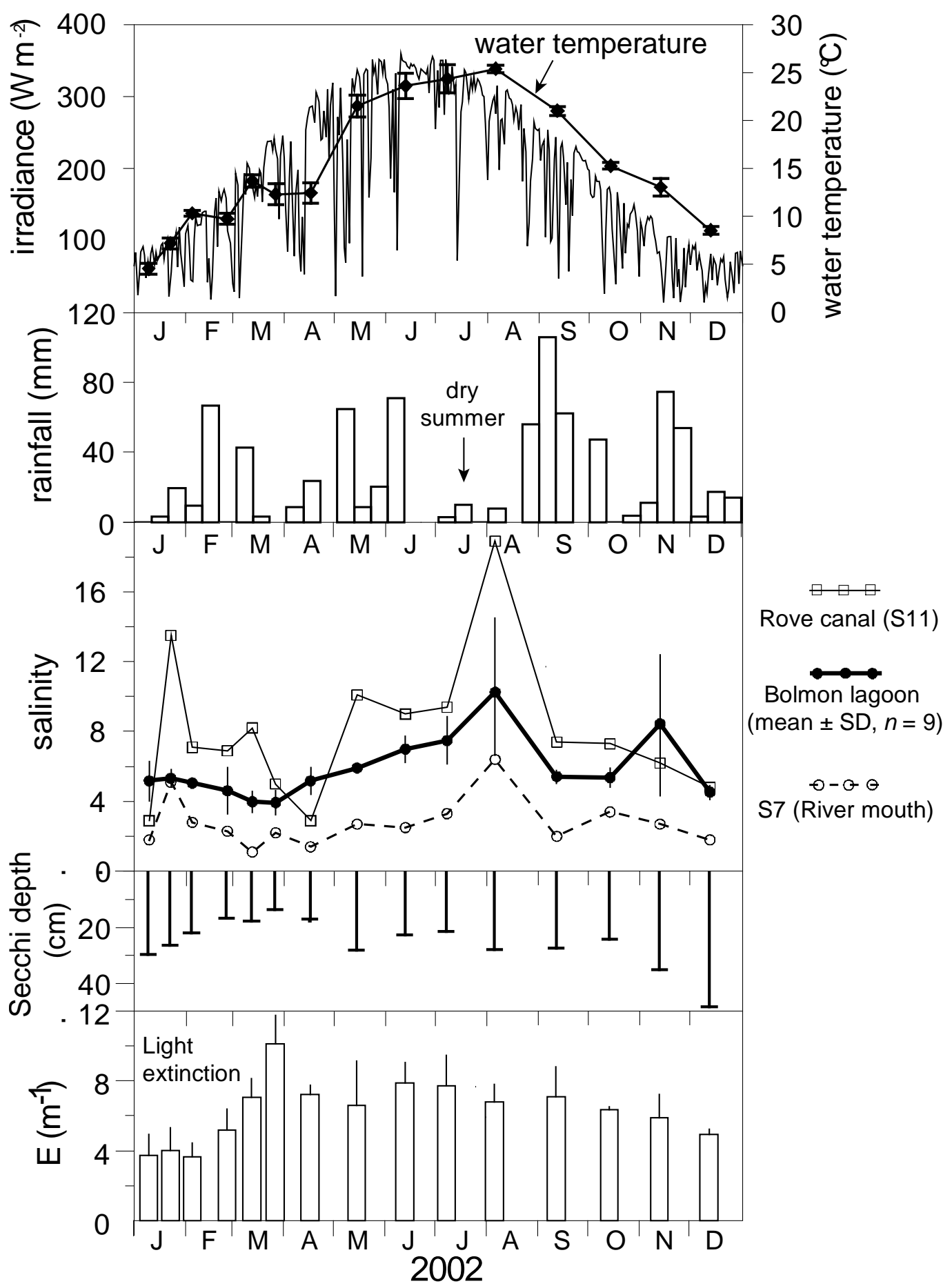

Fig. 2 


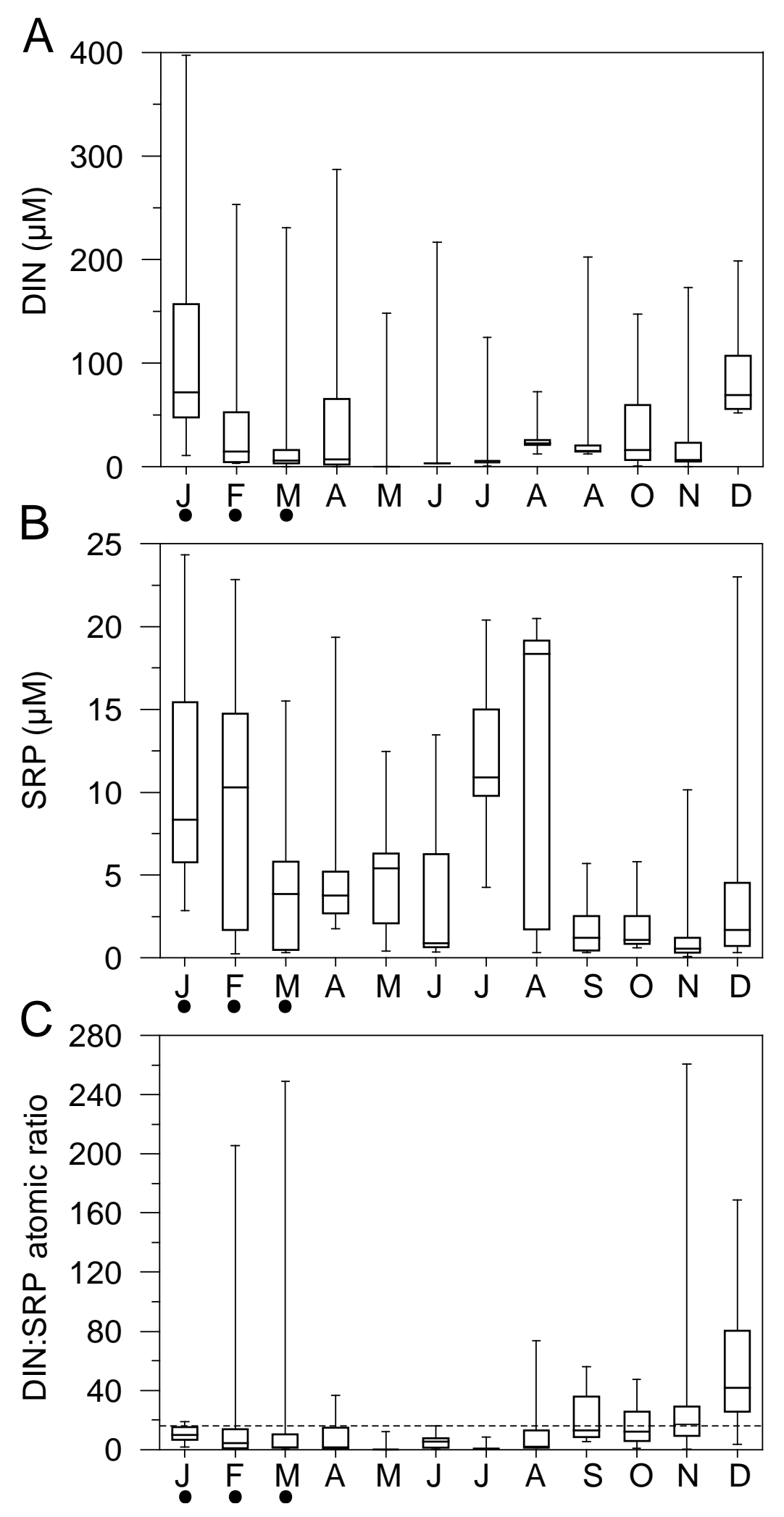

Fig. 3 

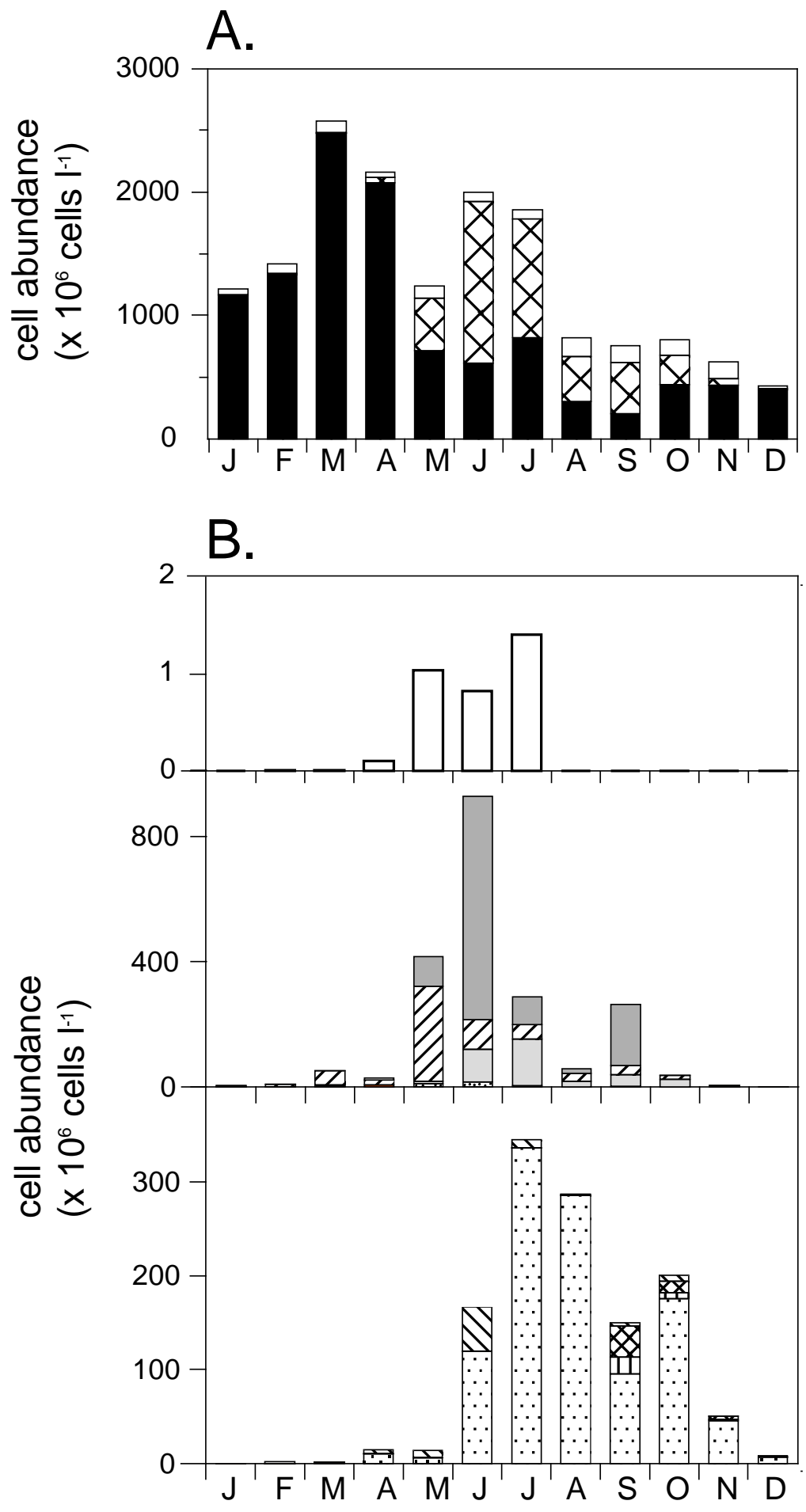

other cyanoprokaryotes:

\section{Nostocales}

Anabaenopsis elenkinii

Chroococcales

$\square$ Aphanothece minutissima

$V / \triangle$ Aphanocapsa delicatissima

- Merismopedia tenuissima

Chroococcus spp.

\section{Oscillatoriales}

NI Limnothrix planctonica

Geitlerinema amphibium

III Planktolyngbya limnetica

$\therefore$ Pseudanabaena limnetica

Fig. 4 
$\%$ biovolume

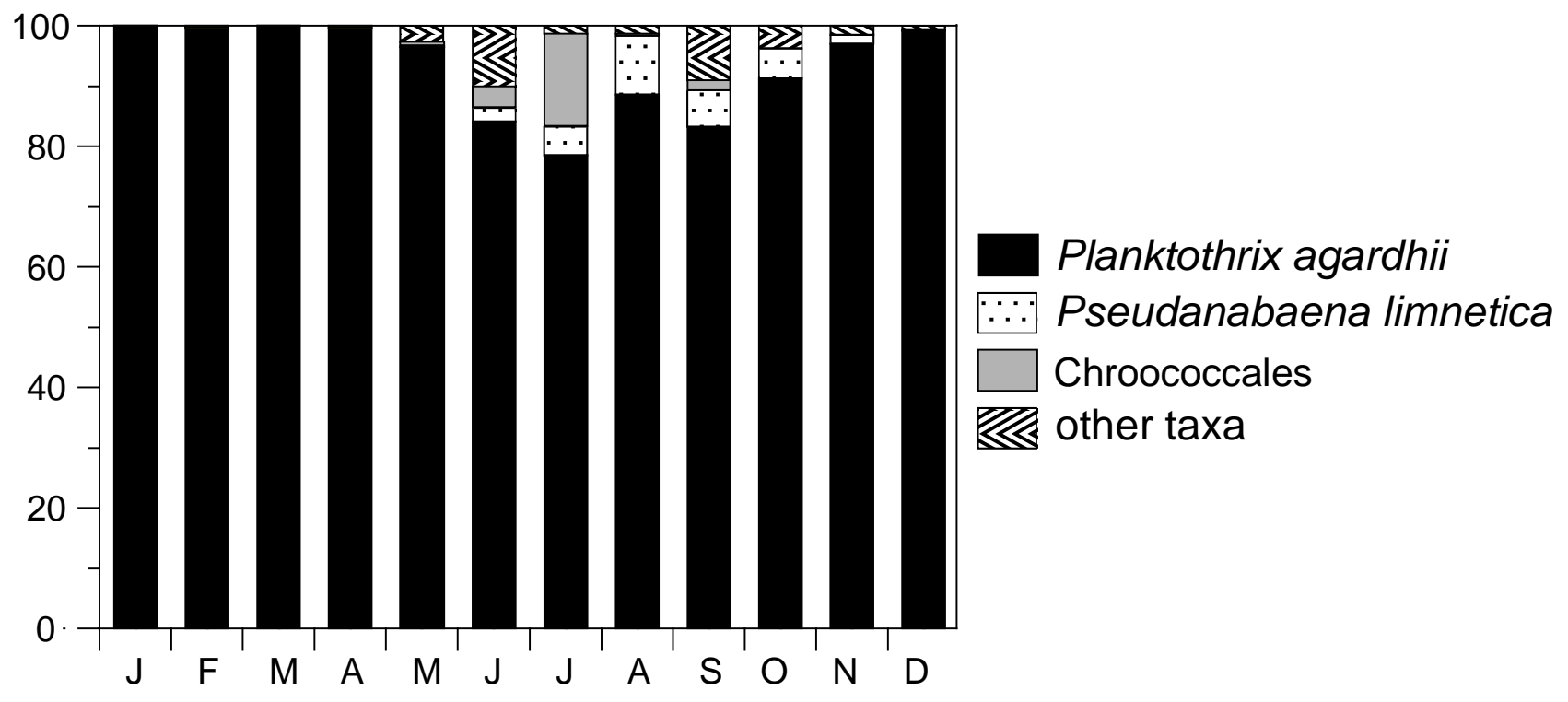

Fig. 5 


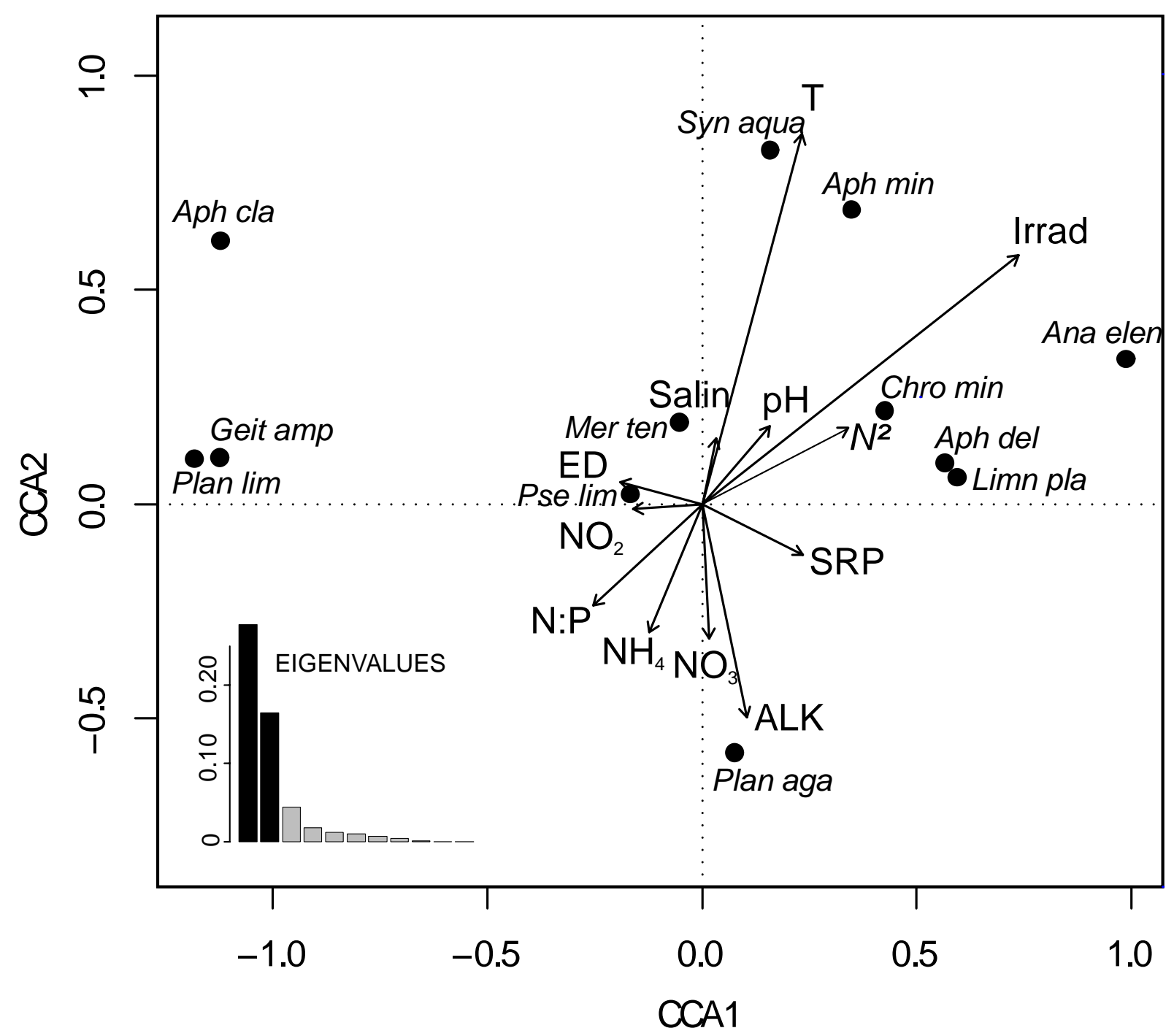

Fig. 6 